\title{
Growth and reproduction performance of sea cucumber (Stichopus sp.) fed with different feed regime
}

\author{
Ketut Maha Setiawati ${ }^{*}$, Zeny Widiastuti ${ }^{1}$, Sari Budi Moria Sembiring ${ }^{1}$, N.A. Giri ${ }^{1}$ \\ ${ }^{1}$ Institute for Mariculture Research, Development and Fisheries Extension, Gondol-Bali, Indonesia
}

\begin{abstract}
Growth and reproduction performance of sea cucumber (Stichopus sp.) fed with different feeding regimes. This study aims to know the effects of different feeding regimes on sea cucumbers' growth and gonad development. Sea cucumbers used in this experiment were collected from the natural habitat in Northern Bali waters. Five individuals of sea cucumber (BW $334 \pm 58 \mathrm{~g}$; TL 22,5 $\pm 3,5 \mathrm{~cm}$ ) were placed in each of four concrete tanks size $0,85 \times 2 \times 0,5 \mathrm{~m}^{3}$ with flow-through water systems. There were two feeding treatments in this study: A) fresh benthos and B) a combination of fresh benthos and seaweed (Ulva and Sargassum). Feed was given as much as 2.5 to $5 \%$, once in the afternoon. Observed variables were the growth and gonad stage and the weight at the end of the experiment. The study showed that the different feeding regimes significantly influenced the sea cucumber growth and gonad weight, but not the gonad stage. Sea cucumber fed with a combination of benthos and seaweed performed better growth and higher gonad weight. The difference in the feed did not affect gonad development.
\end{abstract}

\section{Introduction}

Invertebrate marine animals have high commercial value, particularly sea cucumbers (Holothurians). Other than Holothuria scabra (Teripang Pasir), the sea cucumbers widely caught by the local fishing community is Stichopus sp. (teripang gamat). Several species belong to the Stichopus group i.e.; Stichopus vastus, S. hermanni, and S. quadrifasciatus.

Increasing demand for sea cucumber both from the local and global market has resulted in higher fishing activities. It has led to the population's decrease significantly in the species that are the main fishing target. Up to now, some species listed as high commercial value have become difficult to fish. For example, Holothuria scabra, $H$. fuscogylva, $H$. nobilis, S. chloronotus, S. variegatus, and Thelenota ananas. Therefore, the fishermen were turning their target to other species of sea cucumbers. Sea cucumbers have also received serious attention from CITES because of their possibility of increasing extinction, in particular to those species of sea cucumbers with high commercial value [1].

Reproduction is one of the factors that can be used as a basis or indication for evaluating aquatic resource management, especially for the survival and descendants of an organism or

\footnotetext{
* Corresponding author : mahasetiawati@yahoo.com
} 
population. This approach is carried out to provide information on when can exploit the resources of sea cucumbers, which is in line with the sustainability of these resources in the future. The life's continuity of all living creatures (including sea cucumbers) in nature occurs through rearing or reproduction activities. This activity is a natural process that aims to maintain its existence in nature [2]. This reproduction aspect can also be influenced by environmental factors, including the lunar cycle [3]. Therefore, an assessment of reproductive factors is needed by looking at the possible future threats of extinction on sea cucumber resources in water areas.

Sea cucumbers are marine biota that is omnivorous and also tend to be herbivores [4]. As a low trophic level group, the small sea cucumber $(2.5-5.0 \mathrm{~cm})$ feed consists mainly of attached diatoms and organic detritus. Furthermore, larger sizes eat small mollusks, copepods, diatoms, and seaweed. The culture of sea cucumber, Apostichopus japonicus in China uses the brown algae Sargassum thunbergii to feed [5]. These algae is known to be rich in amino acids and have enough protein content. Other types of algae such as Undaria pinnatifida [6], Gracilaria lemaneiformis [7], and Ulva lactuca [8] also have been reported to use as a protein source for a feed of A. japonicus. Sargassum extract has been used as feed on seed production of sea cucumber, H. scabra in India. While Ulva lactula flour was further used as feed for the larger size of this sea cucumber [9]. Application a combination of Sargassum sp. flour (44\%) and Ulva sp. flour (40\%) is formulated feed produced good growth (368.3\% weight gain) of juvenile sea cucumber $H$. scabra reared in the tank for 120 days [10]. Bentos, cultured in a concrete tank, provides a tremendous growth to seed of sea cucumber, H. scabra. That benthos contains phytoplankton from the diatoms class and melosiraceace family; Naviculaceae; Nitzschiaceae, and zooplankton from the family Acartiidae [11]. However, there was rare information on the application of seaweed Sargassum sp. and Ulva sp. as food for supporting the growth and reproduction of Stichopus sp. Therefore, the objective of this study was to know the effects of different feed on the development and gonad of sea cucumber

\section{Materials and methods}

The broodstock of Stichopus sp. used in this experiment was obtained from Buleleng waters of Bali. The broodstock is reared in four concrete tanks $\left(0.85 \times 2 \times 0.5 \mathrm{~m}^{3}\right)$, equipped with a running water system and aeration to supply the oxygen. Each tank contains five individual sea cucumbers with an average weight of $334 \pm 58 \mathrm{~g}$ and a length of $22.5 \pm 3.5 \mathrm{~cm}$. The treatments were the different feed: broodstock feed with fresh benthos (treatment A), and a combination of fresh benthos, and the mixture of Ulva and Sargassum (treatment B). Benthos was cultured in a concrete tank and harvested every day [12]. Every evening, the feed is given as much as $2.5-5.0 \%$ body weight by visual observation for 111 days. The fresh Ulva and Sargassum were chopped with a machine until they reached a size of 4.5 $\mathrm{mm}$. The seaweed was packaged and stored at a cold temperature of $4{ }^{\circ} \mathrm{C}$ to $20^{\circ} \mathrm{C}$ for more extended periods [13]. Cleaning the bottom of the experimental tank to remove the remainder of the feed and feces was carried out daily before giving the fed.

The observed variables were growth (weight on day 43, 66, 111, and total length on day 62,111 rearings). The total length measurement was carried out using a cloth meter with an accuracy of $0.1 \mathrm{~cm}$. The weight was measured using digital scales to $0.1 \mathrm{~g}$ accuracy. Feed consumption was observed visually by looking at the remaining feed on the next day. At the end of the study, $0.5 \mathrm{M} \mathrm{KCl}$ injection was carried out as much as $0.5-1 \mathrm{cc}$ to remove the internal organs of sea cucumber to obtain gonad weight (gonadal maturity index) [15] and digestive tract weight. The indicators were used to see the characteristics of each stage of the gonad maturity with histology and measurement of eggs with a microscope. 
Stage I : indicates immaturity or immature gonads, the consistency of the oocyst begins to stick to the tubule wall.

Stage II : the gonads develop towards maturity. The consistency of the oocyst appears to grow towards the middle of the tubule.

Stage III : mature gonads (ripe), oocyst consistency, seems to fill the tubular cavity, and Stage IV : empty or spent; it is after the sea cucumbers have spawned [14].

The collected data that includes the growth data were analyzed using T-test and descriptive (graphs), the reproduction rate was analyzed descriptively.

\section{Results}

Bodyweight of Stichopus sp. after 43, 62, and 111 days of rearing with different feeding regimes was shown in Figure 1. Sea cucumber fed with a combination of benthos and seaweed had a higher weight than that only feed benthos.

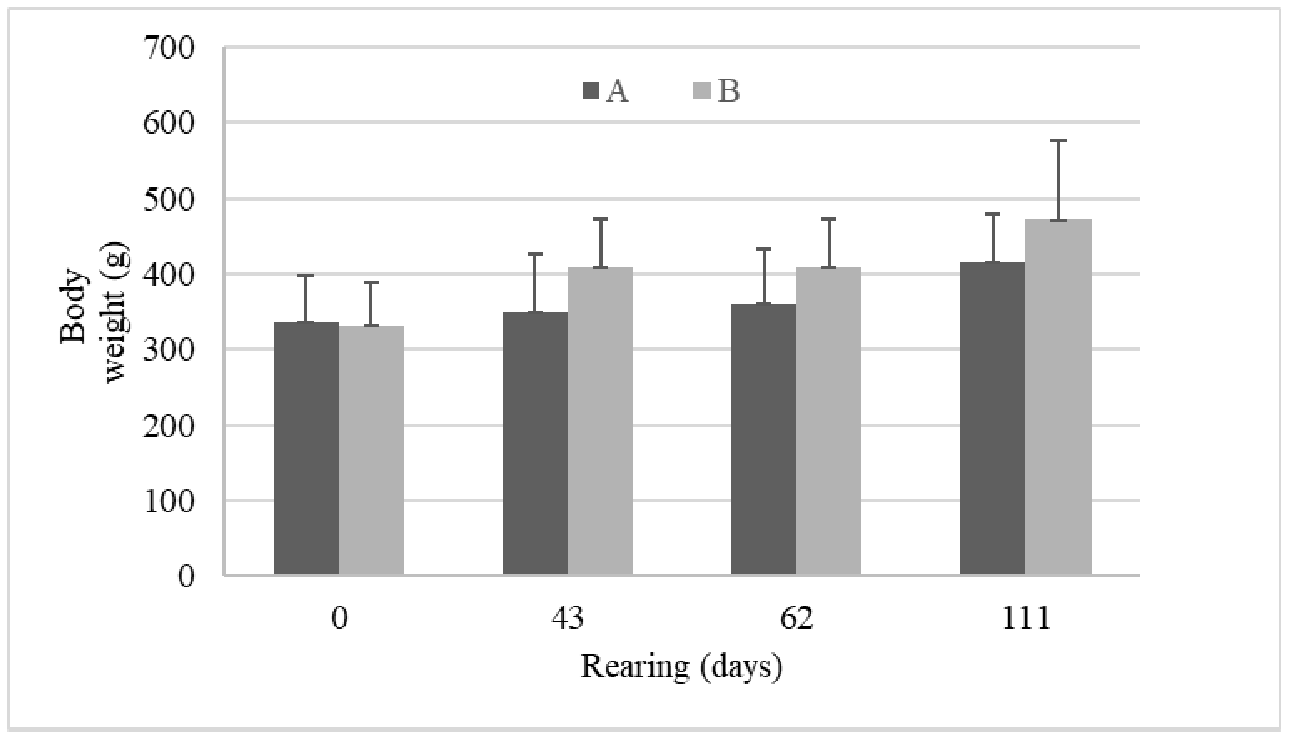

Fig. 1. Bodyweight of Sticophus sp. fed with fresh benthos (A), and combination of fresh benthos and the mixture of Ulva and Sargassum (B).

The total length of Stichopus sp. on day-62 was slightly lower compared to the initial length. However, it was a slight increase on the $111^{\text {th }}$ day of rearing (Figure 2). 


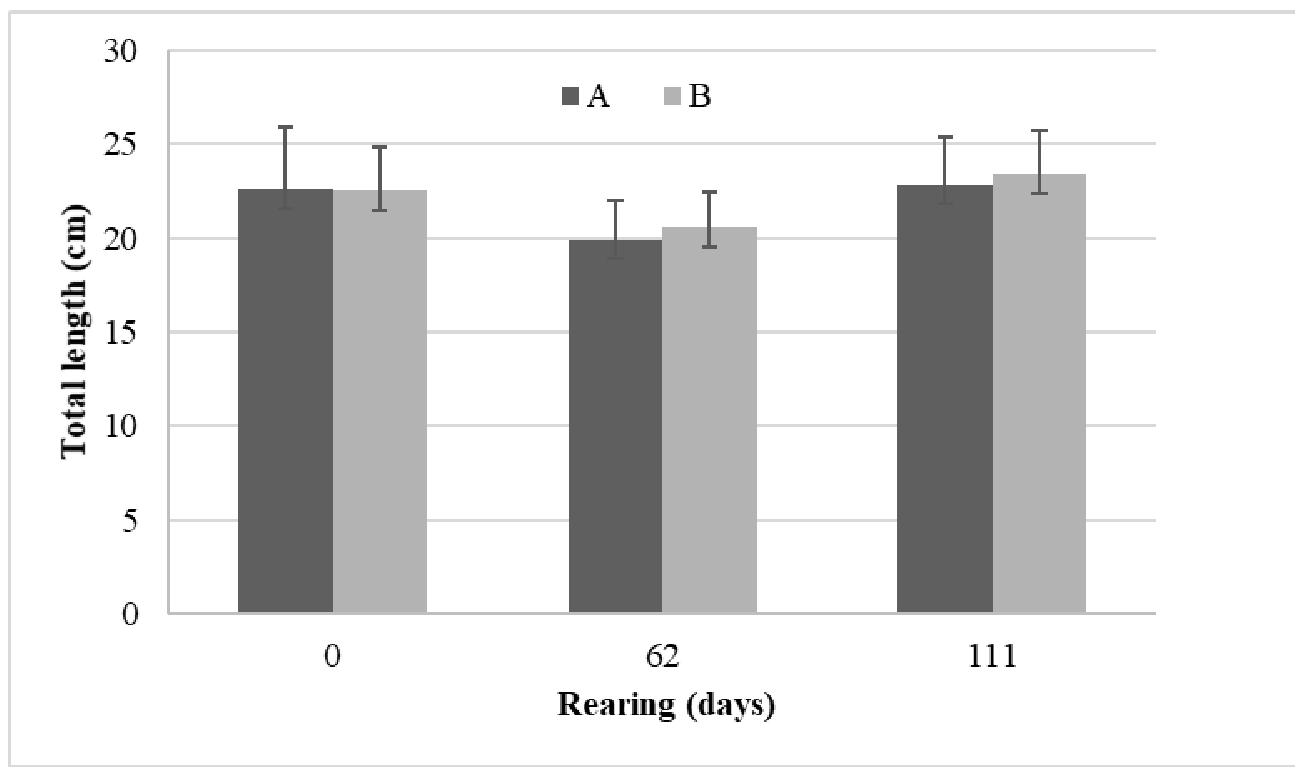

Fig. 2. The total length of Stichopus sp. Fed with fresh benthos (A) and a combination of fresh benthos and Ulva and Sargassum (B).

Figure 1 and Figure 2 show that the suitable variable to measure the growth of sea cucumbers is the weight because it was more consistent than the length. It can also be seen in Table 1. Weight gain of sea cucumber in treatment B was higher (140.3 g) than in treatment A $(80.2 \mathrm{~g})$. The length gain in treatment B is more elevated than treatment $\mathrm{A}$. The t-test showed that the final total length, final body weight, and gonad weight of sea cucumber in treatment B were significantly higher than treatment A. The feed amount was consumed by sea cucumber in treatment $\mathrm{A}$ is $2.5-3 \% \mathrm{BW}$. Meanwhile, in treatment B was 4-5\% BW, higher compared to treatment $\mathrm{A}$.

Table 1. Total length, body weight, specific growth rate (SGR), and gonad weight of Stichopus sp. feed different feeding regimes for 111 days

\begin{tabular}{lll}
\hline Variables & $\mathrm{A}$ & $\mathrm{B}$ \\
\hline Initial total length $(\mathrm{cm})$ & $22.6 \pm 4,5$ & $22,5 \pm 2.5$ \\
Final total length $(\mathrm{cm})$ & $22,9 \pm 2,6^{\mathrm{a}}$ & $23,4 \pm 3.1^{\mathrm{b}}$ \\
Length increase $(\mathrm{cm})$ & 0.3 & 0.9 \\
Initial body weight $(\mathrm{g})$ & $336.2 \pm 62.9$ & $331.6 \pm 56.5$ \\
Final body weight $(\mathrm{g})$ & $442,8 \pm 96.5^{\mathrm{a}}$ & $475,5 \pm 121.1^{\mathrm{b}}$ \\
Weight gain $(\mathrm{g})$ & 80.2 & 140.3 \\
Gonad weight $(\mathrm{g})$ & $18,9 \pm 6.0^{\mathrm{a}}$ & $27,8 \pm 13.9^{\mathrm{b}}$ \\
SGR $(\% /$ day) & 0.195 & 0.309 \\
\hline
\end{tabular}




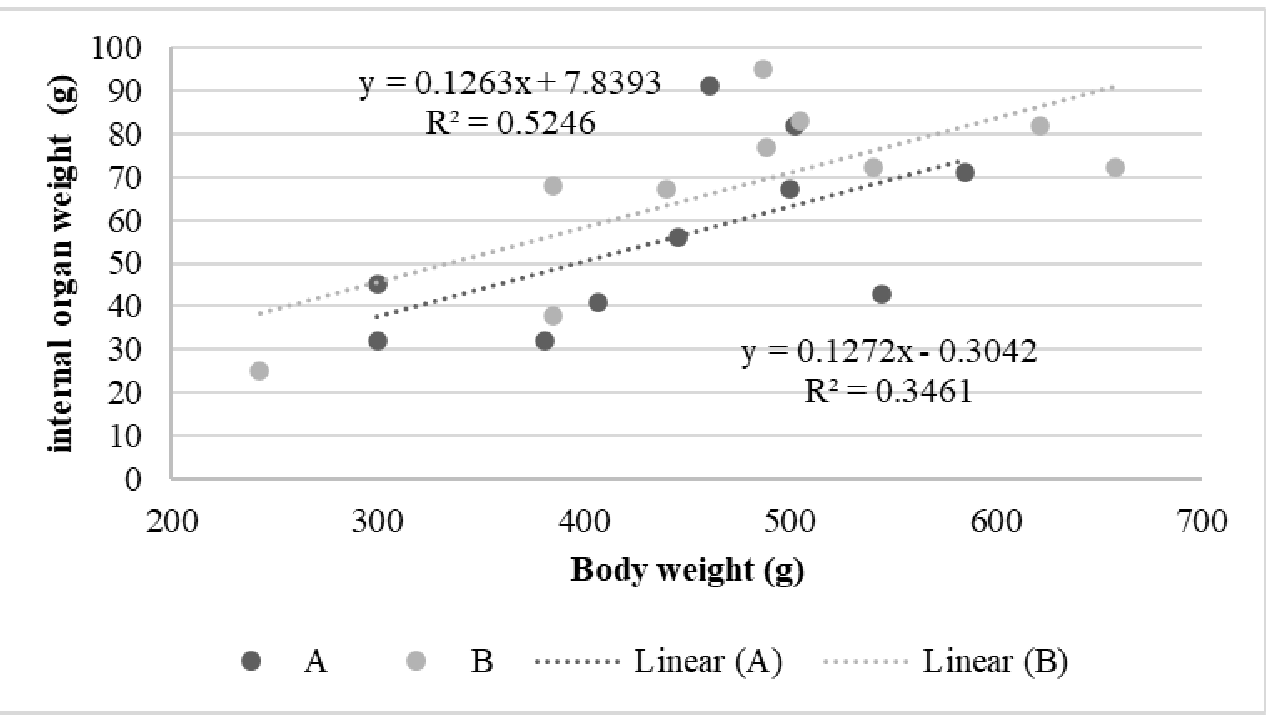

Fig. 3. The relationship between body weight (g) and internal organ weight (g) of Stichopus fed with fresh benthos (A), and combination of fresh benthos and the mixture of Ulva and Sargassum (B).

Figure 3 shows that the relationship between weight and internal organ weight is a linear regression equation. The weight of internal organs will increase when the bodyweight grows.

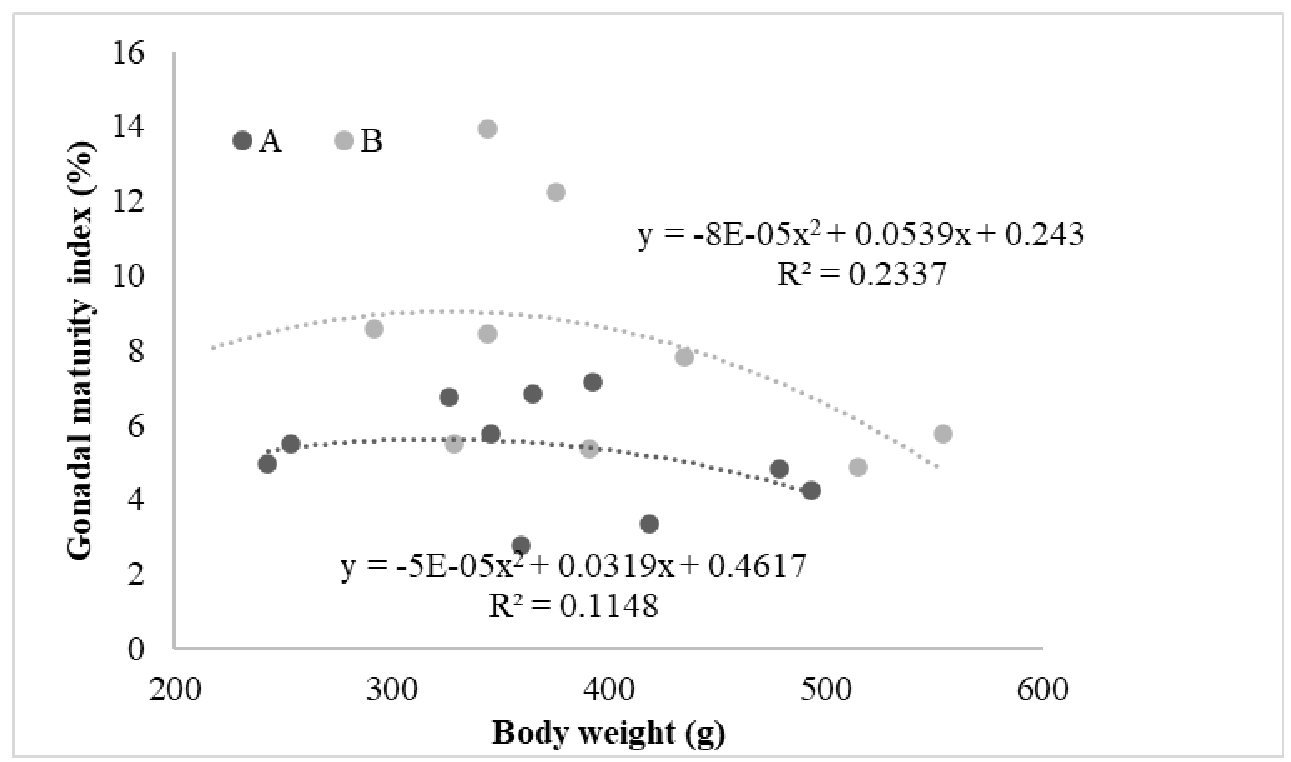

Fig. 4. The relationship between weight and gonadal maturity index of Sichopus sp fed with fresh benthos (A), and combination of fresh benthos and the mixture of Ulva and Sargassum (B).

Figure 4 shows that the relationship between weight and gonadal maturity index [15] in treatment B is higher than treatment A. Thus, gonad B's weight is relatively higher than A. 
As in Table 2, the nutritional content of Ulva, Sargassum, and benthos contains protein, fat, and various vitamins that can stimulate the growth and development of the sea cucumber gonads.

Table 2. The nutritional content of Ulva, Sargassum, and benthos was used in the experiment

\begin{tabular}{llll}
\hline & Ulva $[16]$ & Sargassum $\%(\mathrm{~b} / \mathrm{b})[17]$ & Benthos [10] \\
\hline Protein & $15-26 \%$ & $5.19 \pm 0.13$ & 11.1 \\
Fat & $0.1-0.7$ & 1.63 & 4.8 \\
Ash & $15-26 \%$ & $36.93 \pm 0.34$ (dry weight) & 62.2 \\
$\mathrm{Ca}(\mathrm{mb} / 100 \mathrm{~g})$ & & $1540.06 \pm 6.99$ & \\
$\mathrm{Fe}(\mathrm{mg} / 100 \mathrm{~g})$ & & $132.65 \pm 3.47$ & \\
$\mathrm{P}(\mathrm{mg} / 100 \mathrm{~g})$ & & $474.03 \pm 1.01$ & 16.7 \\
Fiber & $2-5$ & & 78.9 \\
Water & $18.7 \%$ & & \\
\hline
\end{tabular}

At the end of the study, It showed that the number of male sea cucumbers was higher than females. Based on the gonad identification, two females, eight males, and three females, six males were found, in treatment $A$ and treatment $B$, respectively, and one individual was unidentified with the lowest weight of $243 \mathrm{~g}$.
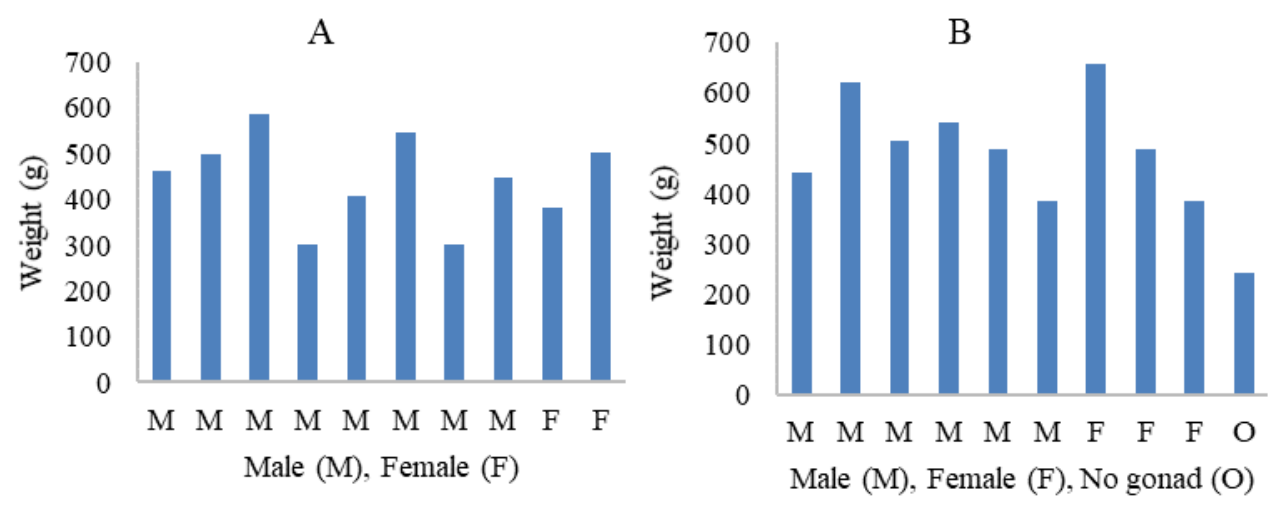

Fig. 5. Sexes of Stichopus sp at the end of the experiment after being fed with fresh benthos (A) and a combination of fresh benthos and the mixture of Ulva and Sargassum (B).

Treatment A was slightly smaller on the egg diameter measurement, with a range of egg diameter between 120-230 microns (Figure 6). Treatment B was more varied; it was between 100-280 microns. Meanwhile, microscopic observation of the gonads showed that the gonads (A) oocyte was not as whole as gonads (B), but histologically, they did not appear differently. In both treatments, the oocyte seemed to fill the tubular tubes (Figure 7). Thus, based on [14], treatments A and B are categorized in stage III, which is considered as the ripe gonads, with the consistency of the oocyte filling the tubular cavity. 


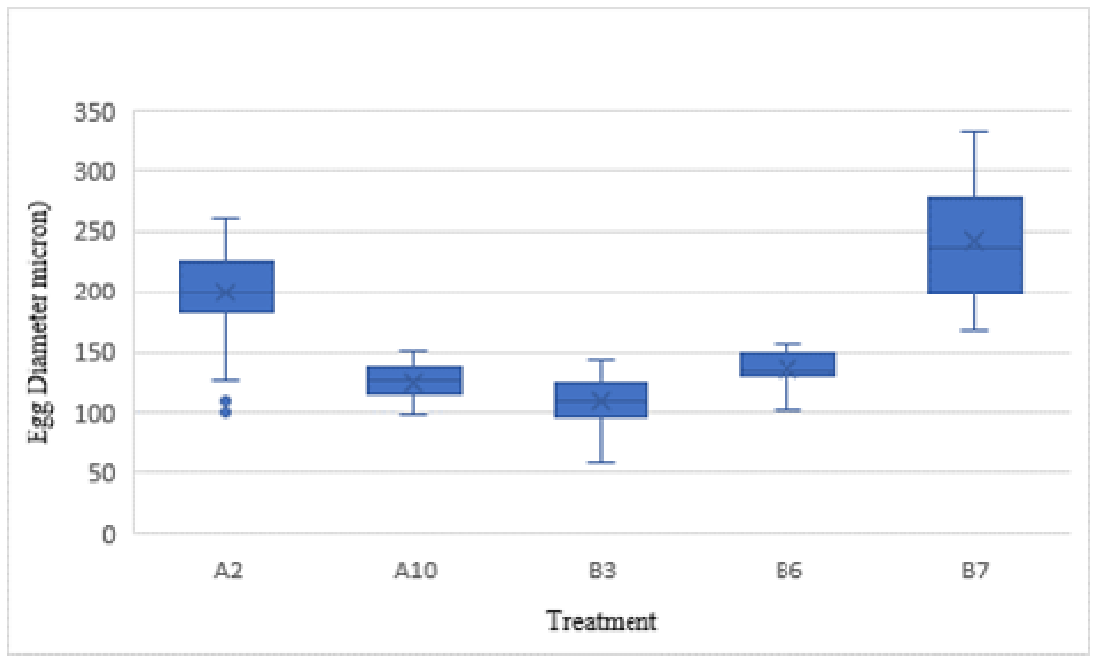

Fig. 6. Egg diameter of Stichopus sp. from histology results in treatment, fresh benthos (A), and combination of fresh benthos and the mixture of Ulva and Sargassum (B).

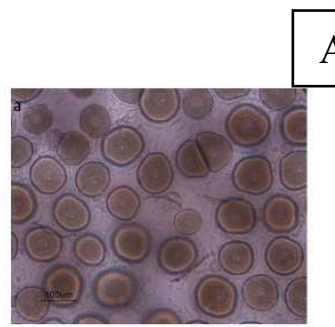

A

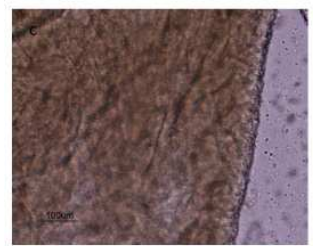

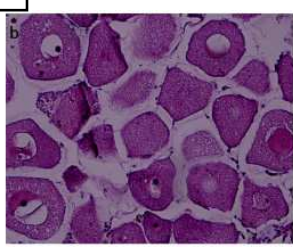

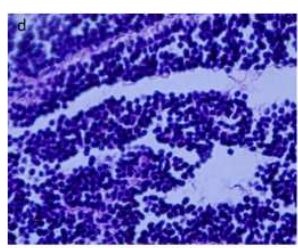

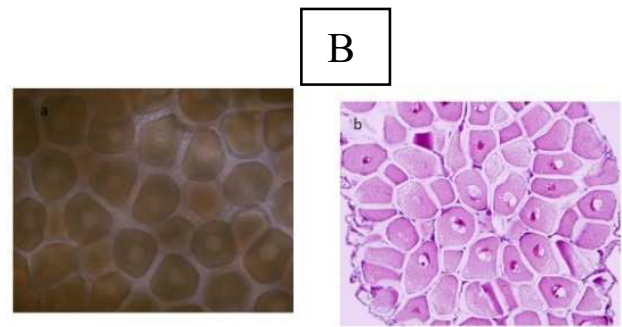
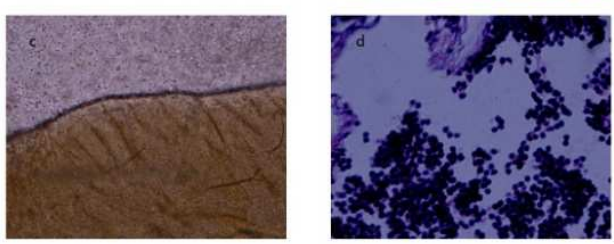

Fig. 7. The gonad of Stichopus sp. with microscopic and histology observation in treatment fresh benthos (A), and combination of fresh benthos and the mixture of Ulva and Sargassum (treatment B).

Note: a. Oocytes with a microscope

b. Sperm with a microscope

c. Oocytes with histology

d. Sperm with histology

\section{Discussion}

Several research studies have used different types of seaweed: Sargassum thunbergii, Ulva lactuca, and Cystoseira indica to study sea cucumber nutrition requirements $[5,6,7,18]$ Stichopodidae contents diatoms, algae, and benthos in intestinal organs [19].

In the present study, the effect of feeding with fresh benthos (A), and combination of fresh benthos and the mixture of Ulva and Sargassum (B) in growth and performance 
gonad of Stichopus sp., showed that at treatment B had higher gonadal growth and weight than treatment A because treatment $B$ had more suitable combinations of feed than treatment $\mathrm{A}$. In the culture of $H$. impatiens, a combination of seaweed has a higher growth rate rather than 1 type of seaweed. The seaweed combination that is used was Jania rubens (red algae) and Caulerpa racemose (green algae), J. rubens and Cystoscira indica (brown algae), J. rubens and C. racemose, $C$. indica and $C$. racemose. The growth of brown algae (C.indica) was higher than green algae (C. racemose) and red algae (J. rubens). The highest growth was $0.5 \%$ per day with a percentage of $2-3 \%$ feeding. The lowest growth was $0.21 \%$ per day with $2 \%$ J. rubens feeding $[18,19]$. In the present study, the combination of brown algae (Sargassum), green algae (Ulva) and benthos gave a better growth than only giving benthos. As well as in H. scabra (teripang pasir) seeds can utilize Sargassum and Ulva for their growth compared to benthos themselves [10]. Even seaweed-based feeding can increase the protein content of the sea cucumber. Feeding Ulva sp. and benthos: Gracilaria sp and benthos can stimulate the process of gonad's rematurization of the $H$. scabra. The protein content of 11-13\% can support the gonad's rematurization process [20]. The sea cucumbers can take advantage of low protein foods such as detritus and seaweed and decay bacterias in organic material [21]. The feeds given to the natural broodstock are spirulina flour and dried marine sediments [22]. Feed Ulva sp. and benthos; Gracilaria sp. and benthos can accelerate the rematurization of gonads of sea cucumbers (H. scabra) . Benthic feed types produced better somatic gonad index and egg diameter than other feed treatments [20]. Sargassum contains vitamin A $489.55 \pm 8.4 \mu \mathrm{RE} / 100 \mathrm{~g}$, Vitamin C $49.01 \pm 0.75 \mathrm{mg} / 100 \mathrm{~g}$. Ulva contains vitamins B1, B2, B12, C, and E. [23]. Ulva from Pameungpeuk (West of Jawa, Indonesia) contains vitamin A less than $0.5 \mathrm{IU} / 100 \mathrm{mg}$ of vitamin B1 (thiamine) and vitamin B2 (riboflavin), each is $4.87 \mathrm{mg} / \mathrm{kg}$ and $0.86 \mathrm{mg} / \mathrm{kg}$. The calcium is $1828 \mathrm{mg} / 100 \mathrm{~g}$ [24]. the use of Sargassum and Ulva can provide a good response to the growth of sea cucumbers [13]. The Stichopodidae contains diatoms, algae, benthos, and inorganic compounds such as inorganic benthos in intestinal organs [25]. Benthos from culture contains phytoplankton, diatoms, melosiraceace, Naviculaceae, Nitzschiaceae, and zooplankton [11]. Benthos contains protein, fat and can be used as feed for the growth and development of gonads [10]. But in this study was better if it was given a mixture of benthos and seaweed. Stichopus sp. with the identified gonads had a bodyweight of $300 \mathrm{~g}$ or more (Figure 5). In treatment A (fresh benthos), the male sea cucumbers were in the weight range of 300-585 g; the females were in the range of 381-503 g. In treatment B (fresh benthos and mixture of Ulva and Sargassum), the male sea cucumbers were 385-622 g, and the females were 385-658 g (Figure 5). The first mature of H. scabra was $16 \mathrm{~cm}$ [26]. The first spawn was in the size of $16.8 \mathrm{~cm}$ [27]. The total length of sea cucumbers in this study for treatment A is $22.9 \pm 2.6 \mathrm{~cm}$, and in treatment, B is 23.4 $\pm 3.1 \mathrm{~cm}$, and it seemed that all the gonads were ripe. But only one individual in treatment

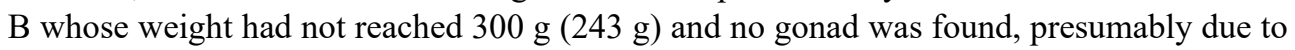
competition in feed and place.

The ratio of male and female sea cucumbers in treatment A was two females: 8 males. Treatment B, three females: 6 males. The sex ratio of $S$. variegatus in the Indo-Pacific coral reef is 100 males: 114 females [28]. Meanwhile, in H. scabra in Un bay, southeast Maluku, more male sea cucumbers than female sea cucumbers $=1: 0.5$ [29]. The sex ratio of males outnumbers the females in H. vagabunda. Likewise, in S. chloronotus there were more males than females $[3,14]$.

The gonads color of the Stichopus herrmanni is reddish-brown in males, while the mature males are orange whereas the immature gonads are creamy [28]. The same is also 
found in this study. S. variegatus on the muddy substrate and a muddy sand bottom, the individual ripening occurred from September to October, individual ripening from November-March. The post-spawning lasted from February to September. From the relationship between water temperature and ripening (gonad index), it is shown that ripening occurred from September to November when the water temperature increased, spawning occurred in the summer (warm season). From May to August, it was the phase to take a break [28].

The average diameter for the ripe oocyst was 180 microns. Absolute individual fecundity was 7000-12000. The average body length of the first mature gonad is $270 \mathrm{~mm}$ in S. variegatus [28]. Fecundity was 300,000-500,000. S. hermani, the total length average of the first mature gonads is $31 \mathrm{~cm}$ with a diameter of 200 microns of the mature oocyte [25].

\section{Conclusions}

Different feeding regimes had significant effects on gonad weight and growth performance of Stichopus sp. Feed consisting of benthos and seaweed (Ulva + Sargassum) gave better growth performance and gonad weight of Stichopus sp.

\section{References}

1. A.W. Bruckner, K.A. Johnson, J.D. Field, SPC Bechede-mer Information Bulletin, (2003)

2. P. Purwati, Lonawarta, 19, 13-2 (1996)

3. Hartati, H. Yanti, J. Ilmu Kelaut. 11, 3 (2006).

4. B. Zhang, D. Sun, Y. Wu. Mar. Sci. 3, (1995).

5. C. Shi, S.L. Dong, F. Wang, Q.F. Gao, X.L. Tian. Aquaculture, 416-417 (2013)

6. J.Y. Seo, I.S. Shin, S.M. Lee, Aquac. Nutr, 17 (2011)

7. Q.F. Gao, Y.S Wang, S.L. Dong, Z.L. Sun, F. Wang, Aquaculture, 319, 1-2 (2011)

8. S. Xia, H. Yang, Y. Li, S. Liu, Y. Zhou, L. Zhang, Aquaculture, 338-341 (2012)

9. S.C. Battaglene, J.E. Seymour, C. Ramofafia, Aquaculture, 178 (1999)

10. N. A. Giri, S. B. M. Sembiring, M. Marzuqi, R. Andamari, J. Ris. Akuakultur, 12, 3 (2017)

11. S.B.M. Sembiring, J. H. Hutapea, K. Sugama, B. Susanto, N.A. Giri, Haryanti. (Badan Litbang KKP, Jakarta 2015)

12. M. Buda, I.N.G. Suparta, A. Rifai. Bulletin teknik litkayasa 16, 2 (2018)

13. Z. Widiastuti, N. K. M. Setiawati, S. B. M. Sembiring, I. N. A. Giri. Seminar Nasional Tahunan XVI, 50-54 (2019)

14. T. Hoareau, C. Conand. Indian Ocean. SPC Beche-De-Mer Information Bull., 15, 4$12(2001)$

15. M. I. Effendie, Fisheries Biology (in Bahasa Indonesia) (Yayasan Pustaka Nusatama, Yogyakarta, 2002)

16. E. N. Dewi, Fakultas Perikanan dan Ilmu Kelautan. Universitas Diponegoro (2018)

17. T. Handayani, Sutarno, A. D. Setyawan, J. Agardh, Biofarmasi 2, 2 (2004)

18. M. A. M. Mahmoud, Egypt J. Aquat. Biol. Fish. 23, 1 (2019)

19. M. Mahmoud, M. I. El-Saman, Babeker, J Fish Aquat. Sci.,163, 12 (2017)

20. S. B. M. Sembiring, I. K. Wardana, N.A. Giri, Haryanti, J. Ris Akuakultur, 12, 2 (2017)

21. N. D. Duy, Seed production of sandfish (Holothuria scabra) in Vietnam (SEAFDEC Aquaculture Department, Tigbauan, 2010)

22. Agudelo, A. Rodriguez, SPC Beche-de-mer Information Bulletin 35, 50-57 (2015) 
23. L. M. Aslan, Budidaya rumput laut (Penerbit Kanisisus, Yogyakarta, 1991)

24. A. Rasyid, Trop. Life Sci. Res. 28, 2 (2017)

25. F. F. Rashidi, E. Kamrani, M. S. Ranjbar, Int. J. of Adv. Appl. Sci., 5, 1 (2018).

26. C. Conand, The fishery resources of Pacific Island countries. Part 2: Holothurians FAO Fisheries Technical Paper (FAO, Rome, 1990)

27. T. Kithakeni, S. G. M Ndaro, Western Indian Ocean J. Mar. Sci., 1, 2 (2002)

28. C. Conand. Bull. Mar. Sci. Coral Reef Paper 52, 3 (1993)

29 Y. Natan, P. A. Uneputty, Y. A. Lewerissa, J.A. Pattikawa, Int. J. Fish. Aquat. Stud., 3, 1 (2015)

30. A. Tehranifard, S. Uryan, G. Vosoghi, S. M. Fatemy, A. Nikoyan, SPC Beche-demer Information Bulletin. 24, 22-27 (2006) 